\title{
A Megacity-Scale Analysis of Sludge Management and Carbon Footprint in China
}

\author{
Gang Zhao ${ }^{1,2}$, Jianguo Tang ${ }^{1 *}$, Chuanting Zhou ${ }^{1,2}$, Cong Wang ${ }^{1,2}$, \\ Xiaojie $\mathrm{Mei}^{3}$, Yuanyuan Wei, ${ }^{1,4}$ Jingcheng $\mathrm{Xu}^{2}$ \\ ${ }^{1}$ Shanghai Urban Construction Design \& Research Institute Groups Co., Ltd., 3447 Dongfang Rd, Shanghai PR China \\ ${ }^{2}$ College of Environmental Science \& Engineering, Tongji University, Shanghai PR China \\ ${ }^{3}$ Yangtze Eco-Environment Engineering Research Center, China Three Gorges Corporation, Shanghai PR China \\ ${ }^{4}$ Shanghai Urban Stormwater Management Engineering \& Technology Research Center, Shanghai PR China
}

Received: 14 July 2021

Accepted: 31 October 2021

\begin{abstract}
With the growing capacity of wastewater treated, a large amount of sludge has been generated in China. Shanghai has 42 wastewater treatment plants (WWTPs), with a total design capacity of $8.5 \times 10^{6} \mathrm{~m}^{3} /$ day. The sludge production per Capita is higher than in other Chinese regions. The sludge management strategy has changed drastically over the past three years in Shanghai. As to the sludge treatment, deep dewatering technologies such as filter-press dewatering and vacuum filter-press dewatering are the most used methods. On the other hand, the ratio of sludge anaerobic digestion and aerobic composting is very low due to the poor sludge quality. Regarding sludge disposal, sludge landfill has been phasing out, but the ratio of sludge incineration has increased significantly. The carbon footprint results show landfill alternatives generally have more greenhouse gas (GHG) emissions than sludge incineration and land use alternatives. The average $\mathrm{CO}_{2}$ per ton dry solids (DS) has reduced from 0.91 in 2019 to 0.67 ton $\mathrm{CO}_{2} / \mathrm{t}$ DS in 2020 thanks to the optimization of sludge disposal. This study suggests deep dewatering treatment followed by incineration is considered the reasonable and sustainable sludge management scenario in a megacity.
\end{abstract}

Keywords: megacity, sludge management, greenhouse gas emission, carbon footprint

\section{Introduction}

With the development of industrialization and urbanization, China has the world's second-largest sewage treatment capacity [1]. Therefore, China has been generating a large amount of sludge [2]. As of

*e-mail: tangjianguo@sucdri.com
2019, the daily wastewater-treatment capacity in China has reached $2.1 \times 10^{8} \mathrm{~m}^{3} / \mathrm{d}$, and the total sludge production in 2019 is estimated roughly at $1.3 \times 10^{7}$ ton DS/year. Sludge, as the by-product of wastewater treatment, has many toxic substances such as pathogens, heavy metals, and some organic contaminants, which can cause serious environmental pollution [3,4]. Nowadays, sludge has been a great challenge in China. More than half of the sludge, in many areas, are not stabilized prior to entering the environment or simply dumped. 
So it is essential to manage, treat and dispose of sludge properly.

It was reported that sludge management processes such as thickening, stabilization, dewatering, drying and incineration, and transportation may account for up to $53 \%$ of the total wastewater treatment plant operating cost [5]. Most of the operating cost is generated from the consumption of electricity and chemicals [6]. Moreover, there is a significant concern associated with GHG emissions (such as $\mathrm{CH}_{4}$ and $\mathrm{N}_{2} \mathrm{O}$ ) from different sludge disposal options, particularly landfills [7]. Research results have shown that sludge management contributes over $50 \%$ of the overall GHG emission from a WWTP [8]. In 2020, China has strengthened its Nationally Determined Contribution (NDC) commitment by announcing that China will strive to peak carbon dioxide emissions before 2030 and achieve carbon neutrality before 2060 [9]. Tremendous efforts are necessary to meet the carbon neutrality target in the waste and wastewater sector, such as accelerating the optimization of sludge management. Concerning GHG emissions, carbon footprint assessment has become a popular approach to quantify the contribution of processes and facilities with respect to global warming [10]. Although different approaches such as life cycle assessment and model-based methods have been addressing carbon footprint in recent years, there is not yet a standardized or fully comprehensive carbon footprint analysis for the sludge line. In addition, many researchers have evaluated the carbon footprint of sludge management on specific project level. A city-level analysis of carbon footprint of sludge management, however, wasn't well studied in China. Given the regional difference, the sludge management strategy can be quite different from one city to another. Particularly in a super big city, the sludge treatment and disposal is more centralized and costly than small cities. The quantification of GHG emissions in the sludge line requires an integration of both a) direct GHG emissions from the sludge production to its final destination, and b) the corresponding indirect emissions associated with the consumptions of energy and materials, and c) offset emissions associated with energy recovery and nutrients resource reuse [7]. With the requirement of GHG quantification for sludge line, the study of carbon footprint of sludge management in a city based on long period of operating data is worth attention.
The preliminary task of this study is to comprehensively analyze the current status of sludge production, sludge treatment and disposal in Shanghai based on the past three years of experience. With a comprehensive carbon footprint sludge-specific methodology, the goal of this research is to evaluate the carbon footprint of sludge management on a megacity (population of more than 5 million) scale from the perspectives of direct emissions, indirect emissions and offset emissions that are typically resulted from resource and energy recovery. The sludge management experience and carbon footprint change over the past three years is analyzed. As the real situation case study with site-specific parameters is performed, the carbon footprint results of hybrid sludge treatment and disposal on a city-level would be presenting new perspectives on low carbon sludge management strategies. Hopefully, this study will help decision-makers to pursue the most sustainable sludge management alternative.

\section{Sludge Management}

\section{Sludge Production in Shanghai}

As of 2020, there are 42 WWTPs in Shanghai, with a total design capacity of $8.5 \times 10^{6} \mathrm{~m}^{3} /$ day. The effluent quality meets Class 1 A of Discharge standard of pollutants for municipal wastewater treatment plant (GB 18918-2002): $\mathrm{COD}<50 \mathrm{mg} / \mathrm{L}, \quad \mathrm{BOD}_{5}<10 \mathrm{mg} / \mathrm{L}$, $\mathrm{SS}<10 \mathrm{mg} / \mathrm{L}, \quad \mathrm{NH}_{3}-\mathrm{N}<8 \mathrm{mg} / \mathrm{L}$. The total sludge production in Shanghai is on average 1,100 tons DS per day in recent three years. As presented in Table 1, due to the more developed economy, the value of Per Capita sludge production has increased from 12.6 to $16.6 \mathrm{~kg}$ $\mathrm{DS} /$ year, and it is higher than the reported value of other megacities in China [11].

\section{Sludge Treatment and Disposal}

The technical routes of sludge treatment in Shanghai in the past three years can be summarized into 5 types, namely centrifugal dewatering + aerobic composting (A-type), anaerobic digestion + filterpress dewatering (B-type), conventional filter-press dewatering (C-type), Vacuum filter-press dewatering

Table 1. Total sludge production, Per Capita sludge production and Per Capita GDP of Shanghai in 2020 and other cities in China.

\begin{tabular}{|c|c|c|c|c|}
\hline City & $\begin{array}{c}\text { Total sludge production } \\
\left(10^{4} \text { ton DS }\right)\end{array}$ & $\begin{array}{c}\text { Per Capita sludge production } \\
\text { (kg DS })\end{array}$ & $\begin{array}{c}\text { Per Capita GDP } \\
\text { (thousand dollars) }\end{array}$ & Year \\
\hline Shanghai & 51.1 & 16.6 & 24.7 & 2020 \\
\hline Eastern city & 30 & 12.6 & 14.5 & 2013 \\
\hline Western city & 12.4 & 4.2 & 6.9 & 2013 \\
\hline Northern city & 10.4 & 7.4 & 16.3 & 2013 \\
\hline
\end{tabular}


(D-type), and centrifugal dewatering + thermal drying (E-type). Basically, centrifugal dewatering is considered conventional sludge dewatering method that can achieve the water content of $80 \%$ and filter-press dewatering is considered deep sludge dewatering method that achieve the water content less than $60 \%$ [12]. There are three ways for the sludge disposal in Shanghai: landfill, incineration and land use. As shown in Fig. 1, combining with the sludge disposal, there are a total of 11 technical routes of sludge management. Therefore, the sludge treatment and disposal route in Shanghai is associated with high complexity, and there is no clear goal for the sludge's final destination.

The percentage of the five sludge treatment and disposal scenarios in the past three years are shown in Fig. 2a) and Fig. 2b). The treatment capacity of sludge centrifugal dewatering + thermal drying (C-type) in the past three years is around 347 ton $\mathrm{DS} / \mathrm{d}$, but the percentage is slightly decreased, from $35 \%$ in 2018 to $29 \%$ in 2020 . The capacity of sludge anaerobic digestion (B type) shows no change at 204 ton DS/d. Similarly, the percentage is also decreasing. Sludge centrifugal dewatering + aerobic composting treatment (A-type) in Shanghai has the smallest capacity in 2019 and 2020, accounting for only 4\% of the total sludge treated. This is because the aerobic composting treatment requires larger land occupation for a unit mass of sludge than other treatment technologies. For this reason, it is not suitable for the city of Shanghai where the economy is highly developed and land resources are tight.

It is worth noting that, the percentage of sludge vacuum filter-press dewatering (D type) has grown rapidly since the year 2018. Given the advantage that lower moisture content (typically 20\%) can be obtained by applying vacuum pressure [13], the percentage has reached $15 \%$ in 2020 . The percentage of conventional filter-press dewatering treatment (C-type) of sludge has also increased significantly to $34 \%$ and $36 \%$ in 2019 and 2020, respectively.

In summary, the focus of sludge treatment in Shanghai lies in the deep dewatering of sludge, which is consistent with many other big cities in the country [11]. According to the plan of the local authorities, sludge deep dewatering followed by sanitary landfill is supposed to be an emergency measure in Shanghai. However, as shown in Fig. 2b), deep dewatering (C type) has become the mainstream technology for sludge treatment. On the other hand, the biological stabilization of sludge such as anaerobic digestion has not received much attention yet, as the strong dependency on imported facilities and the high investment of key equipment have become barriers to the widespread application [14].

With respect to the sludge disposal in Shanghai, landfill, incineration and land use have been the three ways to dispose of the sludge in Shanghai in the past three years. Due to the low cost (as low as 72 dollar/ ton DS) [11], the landfill has been chosen as the most commonly used method in the past, accounting for $50 \%$ of the total in 2018 and $55 \%$ in 2019 . However, landfill is considered unsustainable as it is liable to cause secondary pollution of soil and groundwater resource $[15,16]$. In addition, lack of landfilling spaces is a prevailing problem for big cities, both worldwide and China [18]. Particularly in Shanghai, the percentage of sludge landfilled has been drastically reduced to less than $10 \%$ in 2020 . During our study, many sludge deep dewatering facilities have switched the disposal way from landfill to incineration. As a result, the percentage

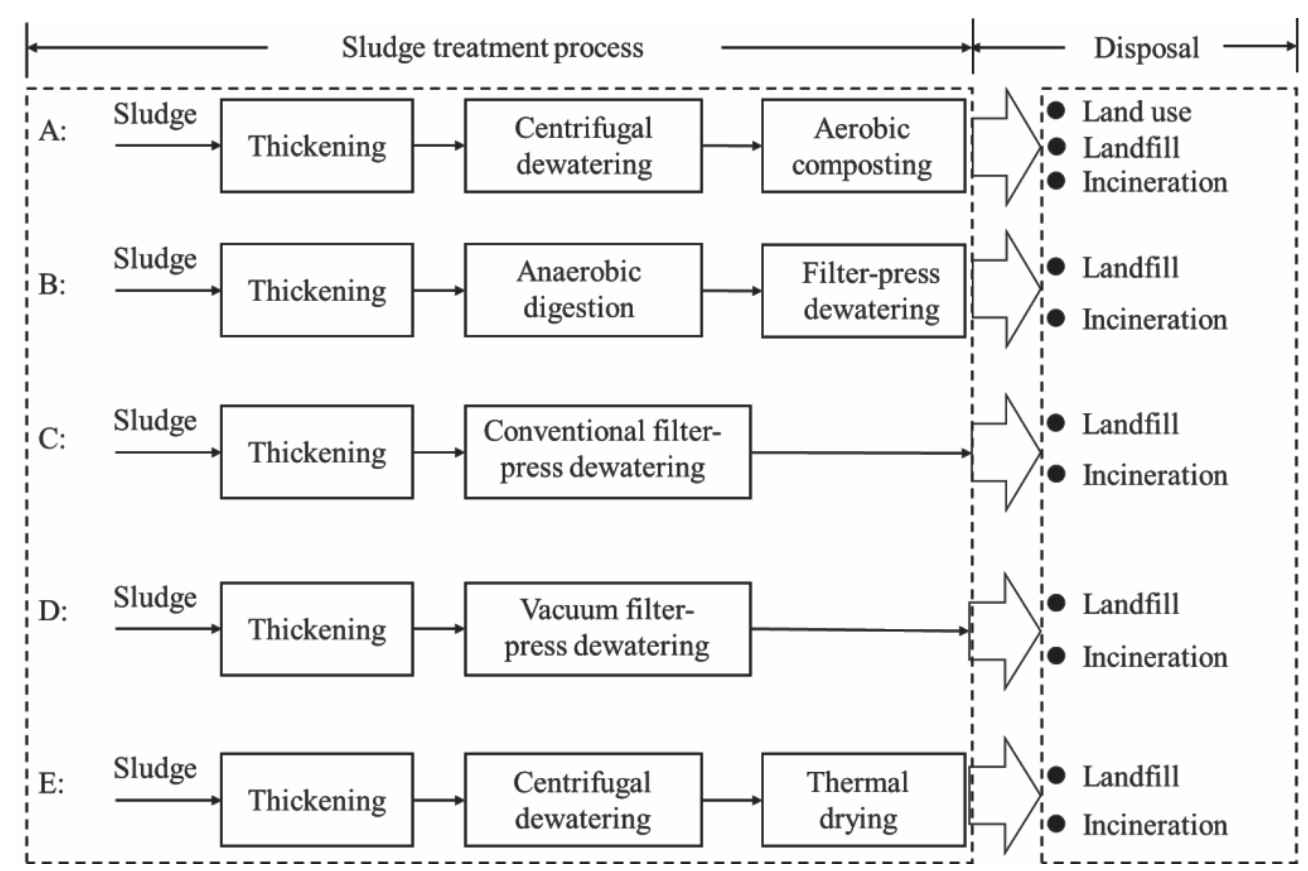

Fig. 1. Sludge treatment process and disposal way in Shanghai. 
(a)
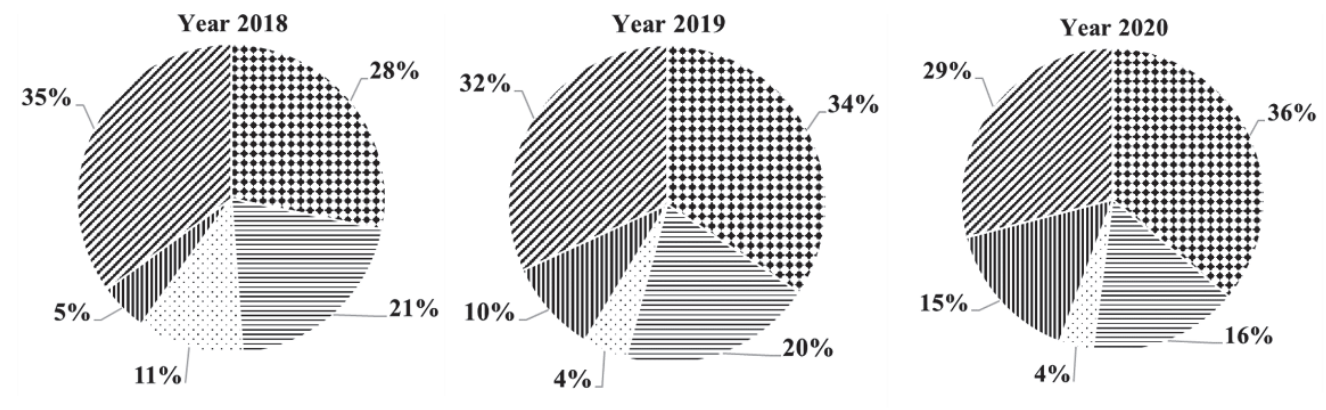

(b)
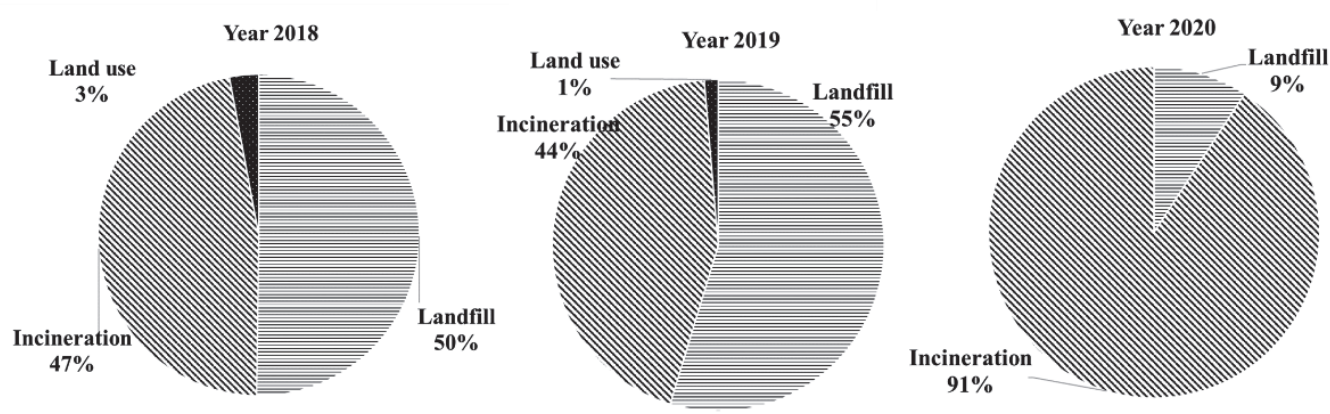

$\equiv$ Landfill $\times$ Incineration $\mathbf{\text { Land use }}$

Fig. 2. The percentage of different sludge treatment a) and disposal b) scenarios in the past three years.

of sludge incineration has increased significantly to $91 \%$ in 2020 .

The land use ratio of sludge application accounts for only $3 \%$ and $1 \%$ in 2018 and 2019 as the end-product is not favored by the local farmers and pollutants concerns as well [18, 19]. In 2020, no sludge product is sent for land use although two aerobic sludge composting facilities are still in use.

\section{Sludge Product Quality}

The chemical composition of sludge products by different treatment types in Shanghai is presented in Table 2. Previous findings have indicated that conventional mechanical dewatering of sewage sludge is not sufficient for self-supporting combustion [20, 21]. Deep-dewatering can reduce the moisture content

Table 2. The chemical composition of sludge products from different sludge treatment types.

\begin{tabular}{|c|c|c|c|c|c|c|}
\hline Sludge treatment type & Process unit & Moisture content $\%$ & VSS \% & $\mathrm{C} \%$ & $\mathrm{~N} \%$ & $\mathrm{P} \%$ \\
\hline \multirow{2}{*}{$\mathrm{C}$} & Raw sludge & 95.6 & 50.3 & 23.9 & 3.3 & 2.4 \\
\hline & Filter-press dewatering & 58.4 & 49.3 & 24.6 & 3.2 & 2.3 \\
\hline \multirow{3}{*}{$\mathrm{E}$} & Raw sludge & 96.2 & 49.5 & 24.8 & 3 & 2.5 \\
\hline & Centrifuge dewatering & 79.5 & 50.1 & 23.4 & 2.9 & 2.5 \\
\hline & drying & 28.6 & 50.1 & 23.4 & 2.9 & 2.5 \\
\hline \multirow{3}{*}{ A } & Raw sludge & 95.4 & 45.6 & 22.3 & 2.9 & 1.9 \\
\hline & Centrifuge dewatering & 80.2 & 46.1 & 22.1 & 2.8 & 1.9 \\
\hline & Aerobic composting & 48.5 & 32.4 & 17.2 & 2.4 & 1.8 \\
\hline \multirow{3}{*}{ B } & Raw sludge & 95.1 & 51.9 & 24.4 & 3.2 & 2.5 \\
\hline & Anaerobic digestion & 96.3 & 35.2 & 18.64 & 2.5 & 2.4 \\
\hline & Filter-press dewatering & 57.5 & 33.6 & 16.7 & 2.4 & 2.4 \\
\hline \multirow{2}{*}{ D } & Raw sludge & 96.2 & 49.6 & 22.9 & 3.5 & 2.3 \\
\hline & Vacuum filter-press dewatering & 26.4 & 48.5 & 21.5 & 3.4 & 2.3 \\
\hline
\end{tabular}

Note: The data in this table is shown as an average value. 
of sludge cake to lower than $55 \%$, enabling sludge product self-supporting combustion [22]. In the case of Shanghai, the five types of sludge treatment processes have been applied to obtain the sludge product with moisture content lower than $60 \%$. As for the D and E treatment types, the moisture content of the sludge product can be reduced to lower than $30 \%$, which is subsequently beneficial for incineration. Generally, C, $\mathrm{D}$, and $\mathrm{E}$ treatment types are not able to break down the organic matter, leading to the sludge product with a high organic faction of the dry solids. The treatment type of $\mathrm{A}$ and $\mathrm{B}$, however, can reduce the organic fractions with a reduction rate of approximately $50 \%$. Compared to the treatment type of $\mathrm{A}$ and $\mathrm{B}$, sludge product of the treatment $\mathrm{C}, \mathrm{D}$ and $\mathrm{E}$ with high organic fraction is supposed to provide high heat value, which makes the sludge incineration profitable. It is beneficial to apply sludge product to the land as far as the nutrients content of sludge is concerned. Landfilling, for sludge that contains high water content and volatile solids content, is not preferable in Shanghai.

\section{Methodology for Carbon Footprint Analysis}

\section{System Boundary}

Following the Greenhouse Gas Protocol (GHG Protocol) set by the World Resources Institute (WRI) and World Business Council for Sustainable Development (WBCSD) [23], the carbon footprint analysis boundary for sludge management in Shanghai consists of direct, indirect and offset emissions. Direct emissions refer to $\mathrm{CH}_{4}$ emission from landfill sites, $\mathrm{N}_{2} \mathrm{O}$ emission from incineration of sludge, and $\mathrm{N}_{2} \mathrm{O}$ emission from land-use sites. It has been reported that carbon in the sludge is considered biogenic (naturally occurring within the carbon cycle and not derived from fossil fuel-related activities), and thus $\mathrm{CO}_{2}$ emissions from organic matter degradation are excluded from reporting $[8,24,25]$. Indirect emissions refer to $\mathrm{CO}_{2}$ emitted by the production of energy (electricity and thermal energy) and chemicals consumed during the operation. The offset GHG emissions are attributed to materials substitution such as fertilizer production avoided by land-use of sludge, and energy recovery (energy production avoided by harvesting biogas from anaerobic digestion or landfill gas system) would be calculated. The carbon footprint is expressed in terms of unit carbon dioxide emission equivalent $\left(\mathrm{kg} \mathrm{CO}_{2} /\right.$ ton DS) by multiplying $\mathrm{CH}_{4}$ by its global warming potential (GWP) of 25 and $\mathrm{N}_{2} \mathrm{O}$ by its GWP of 298 .

\section{Data Sources}

Sludge moisture content and volatile suspended solids (VSS) were measured in accordance with American Public Health Association (APHA) Standard Methods [26]. The nutrient elements, such as C, N, $\mathrm{P}$, were measured by an elemental analyzer (Element Vario EL III, Elementar, Germany). The data used in this study were either measured or provided by $t$ he managers of sludge facilities. Some of the data were taken by field survey. The data in this study were used for carbon footprint calculation can be found in Table 3 .

\section{Direct Emission Calculations}

\section{Fugitive $\mathrm{CH}_{4}$ Emission from the Landfill Site}

When the sludge products are disposed of in a wellmaintained landfill, landfill gas (LFG) is expected to produce as a result of the decomposition of organic materials. LFG is composed of roughly 50\% methane according to Intergovernmental Panel on Climate Change (IPCC) assessment report (AR5). The fugitive emissions in a landfill site can be estimated:

$P_{L G}=V S_{L G} \times D O C_{F} \times 16 / 12 \times M C F \times(1-O X) \times\left(1-R_{L G}\right) \times F_{C H_{4}}$

where $P_{L G}$ is the $\mathrm{CH}_{4}$ emission from the decomposition of sludge in the landfill ( $\mathrm{kg} \mathrm{CH}_{4} /$ ton DS); $V S_{L G}$ is the quantity of sludge received on the VS basis $(\mathrm{kg}$ $\mathrm{VS} /$ ton DS); $M C F$ is the methane conversion factor, which is considered 1 according to IPCC (2006). DOC is the fraction of degradable organic content dissimilated

Table 3. The energy and chemical use for carbon footprint analysis.

\begin{tabular}{|c|c|c|c|}
\hline \multirow{2}{*}{ Process units } & \multicolumn{2}{|c|}{ Energy intensity } & \multirow{2}{*}{ Chemical use (kg/t DS) } \\
\cline { 2 - 4 } & Electricity $(\mathrm{kWh} / \mathrm{t} \mathrm{DS})$ & Thermal energy (MJ/t DS) & $8.6($ PAM) \\
\hline Centrifuge dewatering & 120.3 & - & $5.3($ PAM) \\
\hline Filter-press dewatering & 158.6 & - & - \\
\hline Aerobic composting & 126.3 & $1.68 \times 10^{3}$ & - \\
\hline Anaerobic digestion & 134.5 & $5.22 \times 10^{3}$ & - \\
\hline Vacuum drying & 150.5 & $7.13 \times 10^{3}$ & - \\
\hline Thermal drying & 583.8 & & - \\
\hline
\end{tabular}


to biogas, which is 0.5 (IPCC, 2006); $O X$ is the factor of methane oxidation by soil cover, and the default value is set at 0.25 according to CDM methodology. $R_{L G}$ is the landfill gas recovery efficiency. It is assumed the recovery efficiency is 0.6 for Shanghai, according to UNFCCC, 2008. $F_{C H 4}$ is the weight fraction of methane in the gas, and the default value is $0.5 ;{ }^{16} /{ }_{12}$ is the ratio of molar masses of methane and carbon.

\section{$\mathrm{N}_{2} \mathrm{O}$ Emission from Land Use}

$\mathrm{N}_{2} \mathrm{O}$ is emitted due to the imported nitrogen from sludge for land use by the pathway of nitrification and denitrification. It is estimated by:

$$
N_{L D}=T N_{L D} \times E F N_{L D} \times 44 / 28
$$

where $N_{L D}$ is $\mathrm{N}_{2} \mathrm{O}$ emission resulting from land-use of sludge $\left(\mathrm{kg} \mathrm{N} \mathrm{N}_{2} \mathrm{O}\right.$ /ton $\left.\mathrm{DS}\right) ; T N_{L D}$ is the proportion of nitrogen in the solids ( $\mathrm{kg} \mathrm{N} /$ ton DS); $E F N_{L D}$ is $\mathrm{N}_{2} \mathrm{O}$ emission factor, the value of which is $1.2(\%$ of initial N) [27]; ${ }^{44} / 28$ is the ratio of molar masses of nitrous oxide and nitrogen.

\section{$\mathrm{N}_{2} \mathrm{O}$ Emission from Sludge Incineration}

The $\mathrm{N}_{2} \mathrm{O}$ emission from the sludge incineration can be estimated by the following equations:

$$
\begin{gathered}
N_{I N}=T N_{I N} \times E F_{I N} \times 44 / 28 \\
E F_{I N}=161.3-0.140 \times T_{F}
\end{gathered}
$$

where $N_{I N}$ is the $\mathrm{N}_{2} \mathrm{O}$ emission resulting from solids incineration ( $\mathrm{kg} \mathrm{N} \mathrm{N}_{2} \mathrm{O}$ /ton DS); $T N_{I N}$ is the nitrogen content of sludge for incineration ( $\mathrm{kg} \mathrm{N} /$ ton DS); $E F_{I N}$ is $\mathrm{N}_{2} \mathrm{O}$ emission factor $\left(\mathrm{kg} \mathrm{N}_{2} \mathrm{O} /\right.$ ton DS) and its value is calculated by Equation (4)[28]; ${ }^{44} / 28$ is the ratio of molar masses of nitrous oxide and nitrogen; $T_{F}$ is the incineration Kelvin temperature $\left({ }^{\circ} K\right)$. The temperature is assumed $875^{\circ} \mathrm{K}$ according to the field survey.

\section{Indirect Emission Calculations}

\section{$\mathrm{CO}_{2}$ Emission Related to Electricity}

The electricity consumption during the sludge treatment and disposal process result in indirect $\mathrm{CO}_{2}$ emission. It is estimated by:

$$
E_{E L E}=\sum_{i} E_{U N I T, i} \times E F_{G R I D}
$$

where $E_{E L E}$ is the $\mathrm{CO}_{2}$ emission due to electricity consumption ( $\mathrm{kg} \mathrm{CO} /$ ton DS); $E_{U N I T, i}$ is the electricity consumption of each unit (kWh);EF $F_{\text {GRID }}$ is the regional grid emission factor, which varies against energy source of the power plant. The grid emission factor used in this study is $0.81 \mathrm{~kg} \mathrm{CO} / \mathrm{kWh}$ according to the East China grid.

\section{$\mathrm{CO}_{2}$ Emission Related to Chemical Consumption}

This $\mathrm{CO}_{2}$ emission caused by the chemical consumption during the sludge treatment process is calculated by Equation (6):

$$
E_{C H E}=\sum_{j} M_{j} \times E F_{C H E, j}
$$

where $E_{C H E}$ is the indirect $\mathrm{CO}_{2}$ emission due to chemical consumption in the plant ( $\mathrm{kg} \mathrm{CO}_{2}$ /ton DS); $M$ is the chemical consumption ( $\mathrm{kg} /$ ton DS); $E F_{C H E, j}$ is emission factor for $\mathrm{j}$ type of chemical use $(\mathrm{kg} \mathrm{CO} / \mathrm{kg})$; $j$ is the chemical type. The emission factor for polyacrylamides (PAM) and poly aluminium chloride (PAC) is 4.2 , and $0.18 \mathrm{~kg} \mathrm{CO}_{2} / \mathrm{kg}$, respectively [29].

\section{$\mathrm{CO}_{2}$ Emission Related to Thermal Energy}

Thermal energy was required for the digester temperature maintenance as well as for the thermal drying of sludge. The thermal energy requirement for digesters and their $\mathrm{CO}_{2}$ emission is calculated as follows:

$$
T E_{A D}=Q_{A D, S L} \times S G_{S L} \times\left(T_{D}-T_{S}\right) \times C_{S L}+U \times A \times\left(T_{D}-T_{A}\right)
$$

$$
E_{A D}=T E_{A D} \times 0.05
$$

where $T E_{A D}$ is the energy required to heat influent sludge to the digestion temperature (MJ/ton DS); $Q_{A D, S L}$ is the flow of influent sludge (ton DS); $S G_{S L}$ is the specific gravity of sludge (ton $/ \mathrm{m}^{3}$ ); $T_{D}$ is the digestion temperature $\left({ }^{\circ} \mathrm{C}\right) ; T_{S}$ is the influent sludge temperature $\left({ }^{\circ} \mathrm{C}\right) ; C_{S L}$ is the specific heat of sludge $\left[\mathrm{MJ} /\left(\operatorname{ton}^{\circ}{ }^{\circ} \mathrm{C}\right)\right] ; U$ is the heat loss from the digester $\left[\mathrm{W} /\left(\mathrm{m}^{2.0} \mathrm{C}\right)\right] ; A$ is the surface area of the interfaces where the heat loss occurs $\left(\mathrm{m}^{2}\right)$; $T_{A}$ is the ambient temperature $\left({ }^{\circ} \mathrm{C}\right) ; E_{A D}$ is the indirect $\mathrm{CO}_{2}$ emission due to thermal energy consumption in ( $\mathrm{kg} \mathrm{CO} /$ ton DS); 0.05 is the $\mathrm{CO}_{2}$ emission factor for thermal energy $(\mathrm{kg} \mathrm{CO} / \mathrm{MJ})$. The energy for sludge thermal drying can be estimated based on the previous research [17] and then the corresponding $\mathrm{CO}_{2}$ emission can be calculated by Equation (8).

\section{Offset Emission Calculations}

\section{Offset $\mathrm{CO}_{2}$ Emission Related to Energy Recovery}

Energy is recovered in the form of biogas through anaerobic digestion of sludge. The offset $\mathrm{CO}_{2}$ emission 
related to the energy of biogas production is estimated by using Equations (9) and (10):

$$
\begin{gathered}
E_{B G}=V S_{S L, A D} \times D R_{V S} \times Y_{B G} \times F_{M} \times H_{M} \\
O E_{B G}=E_{B G} \times 0.05
\end{gathered}
$$

where $E_{B G}$ is the estimated energy recovery from anaerobic digestion (MJ/ton DS); $V S_{S L, A D}$ is the volatile solids content of the sludge (ton VS/ton DS); $D R_{V S}$ is the destruction rate of $\mathrm{VS}(\%) ; Y_{B G}$ is the biogas yield of the sludge $\left(\mathrm{m}^{3}\right.$ biogas $/ \mathrm{kg}$ VS reduction), typically $0.9 ; F_{M}$ is the methane content of biogas by volume (\%), typically $62 ; H_{M}$ is the lower heating value of methane $\left(\mathrm{MJ} / \mathrm{m}^{3}\right)$, typically $37 \mathrm{MJ} / \mathrm{m}^{3} ; O E_{B G}$ is the offset emission by energy recovery from anaerobic digestion ( $\mathrm{kg} \mathrm{CO} /$ ton DS).

Energy is recovered as the landfill gas is captured at the landfill site in Shanghai. The collected landfill gas energy and the offset emissions can be estimated by Equations (11) and (12):

$$
\begin{gathered}
E_{L G, R}=P_{L G} \times R_{L G} \times H_{M} \\
O E_{L G, R}=E_{L G, R} \times 0.05
\end{gathered}
$$

where $E_{L G, R}$ is the recovered landfill gas energy $(\mathrm{MJ} /$ ton DS); $P_{L G}$ is the $\mathrm{CH}_{4}$ production from the decomposition of sludge in the landfill ( $\mathrm{kg} \mathrm{CH} /$ ton $\mathrm{DS}) ; R_{L G}$ is the capture rate of landfill gas $(\%) ; H_{M}$ is the lower heating value of methane $(\mathrm{MJ} / \mathrm{kg}) ; O E_{L G, R}$ is the offset emission by the recovered landfill gas energy $\left(\mathrm{kg} \mathrm{CO}_{2} /\right.$ ton DS).

\section{Offset $\mathrm{CO}_{2}$ Emission Related to Sludge Land Use}

Sludge can be applied as a substitute for fertilizer because it contains certain amounts of effective organic fertilizer elements $\mathrm{N}$ and $\mathrm{P}$ [30]. Thus, sludge land use can reduce $\mathrm{CO}_{2}$ emissions from the production of chemical fertilizers. About $61 \%$ of $\mathrm{N}$ and $70 \%$ of $\mathrm{P}$ (weight ratio) in sludge are available [31]. Therefore, the avoided $\mathrm{CO}_{2}$ emission from sludge land application could be calculated by the following equation:

$$
O E_{L U}=0.61 \times S_{N} \times 5.29+0.7 \times S_{P} \times 0.51
$$

where $O E_{L U}$ is the offset $\mathrm{CO}_{2}$ emission by fertilizer substitution from the land application $\left(\mathrm{kg} \mathrm{CO}_{2}-\right.$ eq/ton DS); $S_{N}$ is the nitrogen content of sludge (kg N/ton DS); $S_{P}$ is the phosphorus content of sludge ( $\mathrm{kg} \mathrm{P} /$ ton DS); The emission factor for nitrogen and phosphorus fertilizer production is $5.29 \mathrm{~kg} \mathrm{CO} / \mathrm{kg}$ and $0.51 \mathrm{~kg} \mathrm{CO} / \mathrm{kg}$, respectively [32].

\section{Carbon Footprint Results and Discussion}

The carbon footprint of the eleven different sludge treatment scenarios is shown in Fig. 3. The overall GHG emissions for the eleven sludge management scenarios in Shanghai range from 437 to $1,722 \mathrm{~kg}$ $\mathrm{CO}_{2} /$ ton DS. For the landfill scenarios, direct fugitive $\mathrm{CH}_{4}$ emissions at the disposal site (landfill) are identified

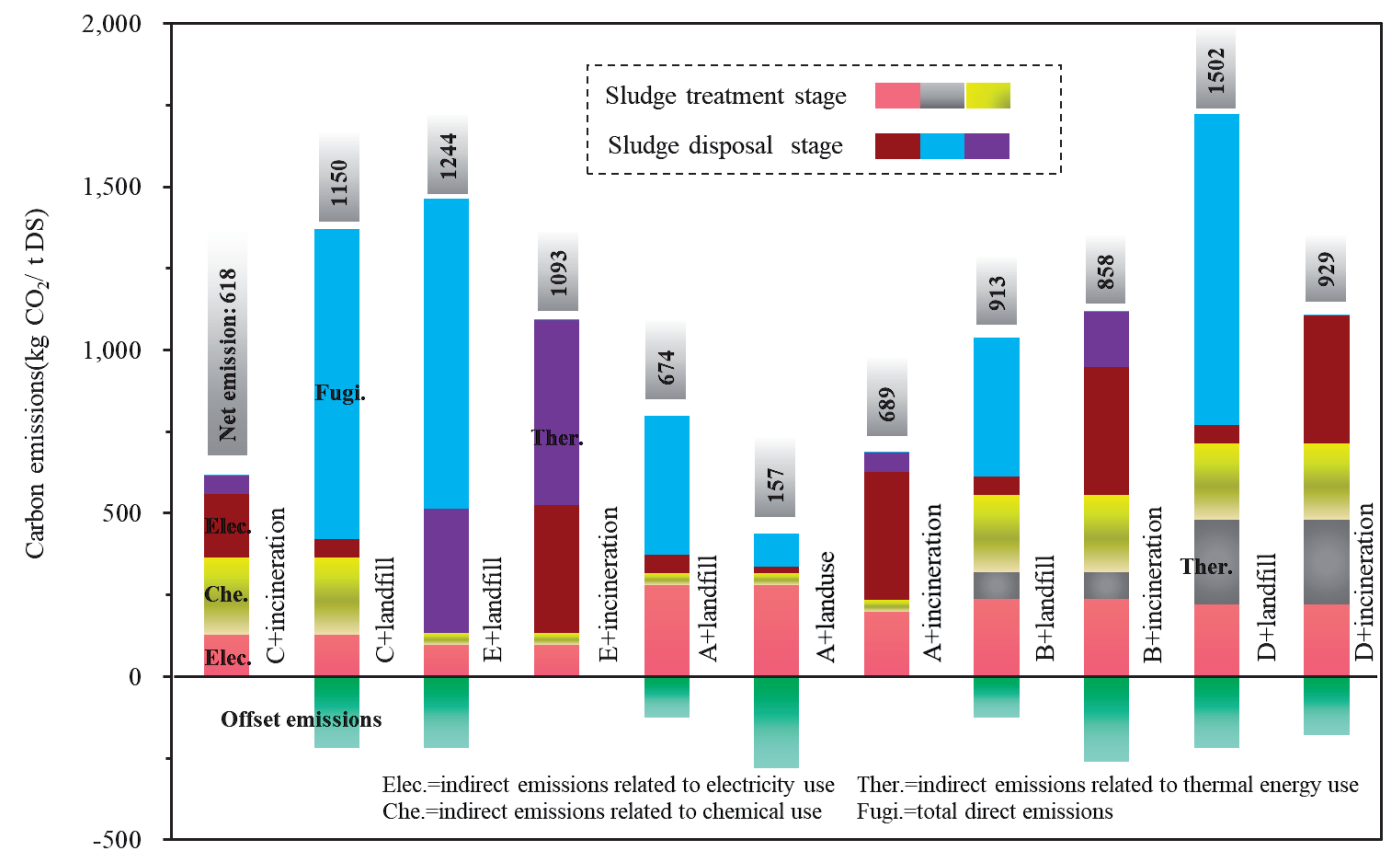

Fig. 3. Carbon footprints of different sludge management scenarios. 
a)

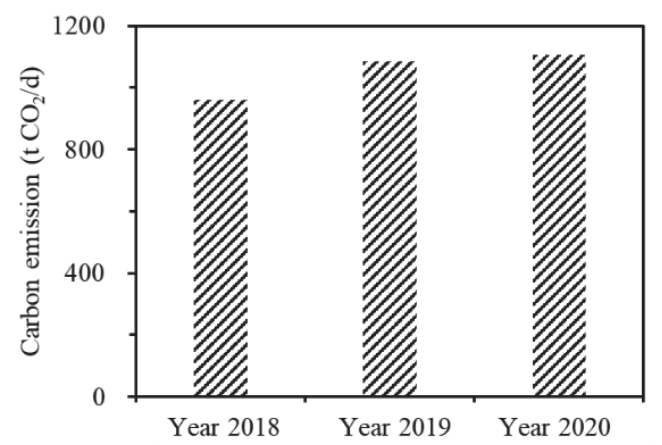

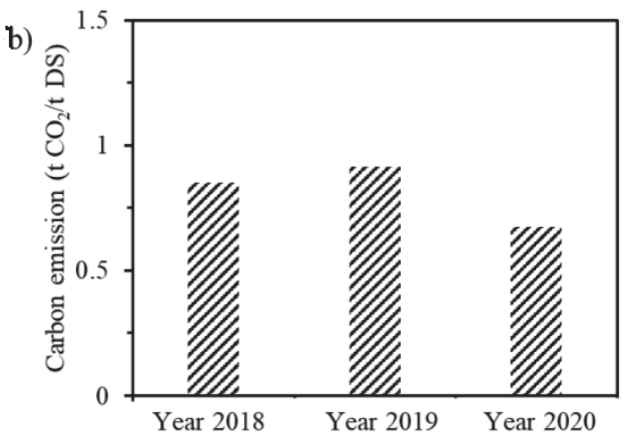

c)

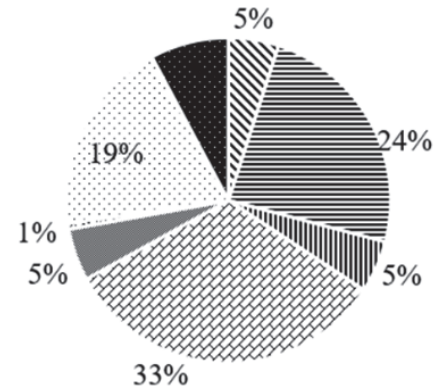

Year 2018

s $\mathrm{C}+$ incineration $\equiv \mathrm{C}+$ landfill

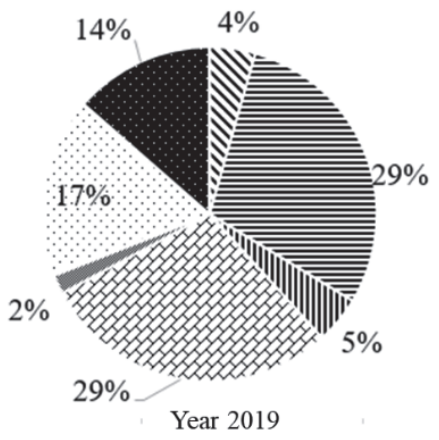

" E+landfill $\approx \mathrm{E}+$ incineration

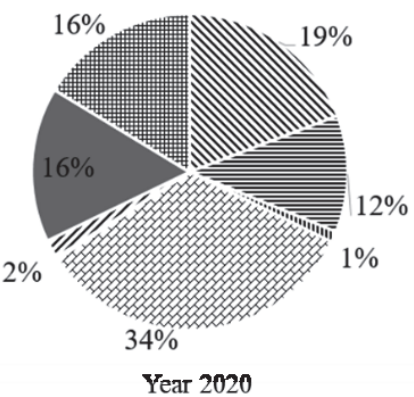

Year 2020

- A+landfill $\quad \because A+$ landuse

- B+incineration D+landfill

* $\mathrm{D}+$ incineration

Fig. 4. Total GHG emission per day a), average GHG emission per ton DS b), the contribution to the overall GHG emission for each sludge treatment and disposal scenario c).

as the major GHG contributors positioning sludge treatment type D +landfill, E+landfill and $\mathrm{C}+$ landfill at the three largest $\mathrm{CO}_{2}$ emitters. It is worth noting that sludge treatment types $\mathrm{A}+$ landfill and $\mathrm{B}+$ landfill have less GHG emissions thanks to the VS reduction in the sludge biological treatment stage. For the incineration scenarios, the indirect emissions regarding electricity, chemicals and thermal energy consumption are the primary contributors to the overall emission, whereas the direct fugitive $\mathrm{N}_{2} \mathrm{O}$ emission is negligible (less than 1\%) despite the different sludge treatment types. Sludge treatment type $\mathrm{C}+$ incineration scenario shows the relatively lowest emission $\left(618 \mathrm{~kg} \mathrm{CO}_{2} /\right.$ ton DS) compared to the other incineration scenarios, suggesting that deep dewatering followed by incineration is a sustainable way to dispose of sludge in the large and populous urban areas.

The most recommended scenario, as can be seen in Fig. 3, is sludge treatment type Atland use (437 $\mathrm{kg} \mathrm{CO}_{2}$ /ton DS emission). However, due to the high concentration of heavy metals and microplastics [33] in the solids, this option was discarded eventually in Shanghai. It should be also noted that the offset emissions that correspond to landfill gas recovery, biogas recovery, and combustion heat recovery and nutrients reuse are regarded as reduction on the overall GHG emission. Consequently, each sludge management scenario that has offset emission shows a lower net GHG emission in the end.
As can be seen in Fig. 4a), the overall GHG emissions for the year 2018, 2019 and 2020 are 959, 1085 and $1105 \mathrm{t} \mathrm{CO}_{2} / \mathrm{d}$, respectively. The GHG emission per day has slightly increased in the year of 2019 and 2020 compared to 2018 due to the increasing amount of sludge treated. Nevertheless, as shown in Fig. 4b), the average GHG emission per ton DS has decreased from $0.91 \mathrm{t} \mathrm{CO}_{2} /$ ton $\mathrm{DS}$ in 2019 to $0.67 \mathrm{t} \mathrm{CO}_{2}$ /ton DS in 2020. It is shown that in Fig. 4c), the sludge treatment type E+incineration scenario has been the largest emitter in the three years. Sludge treatment type $\mathrm{B}+$ landfill scenario was not found in the contribution to the overall GHG emissions in 2020. It was reported that the percentage of EU-15 countries adopting landfill disposal decreased from $33 \%$ to $15 \%$ significantly between 1992 and 2005 [34]. As an economically developed area, Shanghai has been abandoning the landfill as a disposal alternative because of the limited landfill capacity and the increasing concerns over the associated environmental impacts. As expected, the average GHG emission per ton DS has correspondingly reduced for fewer landfill scenarios $\mathrm{CO}_{2}$ contribution.

\section{Conclusions}

Sludge production has increased annually in Shanghai city. Filter-press dewatering, and centrifugal 
dewatering followed by thermal drying were the two main technologies for sludge treatment. For the reasons of technology barrier, poor sludge quality and limited land resources, biological sludge stabilizing methods such as anaerobic digestion and aerobic composting are used to handle a small portion of sludge produced. Landfill and incineration used to be the two most applied methods for sludge disposal. Over the three years, the situation has changed that sludge landfill phased out, and incineration has become the dominant way to dispose of the sludge ( $90 \%$ of the total). Nonbiological sludge treatment products followed by landfills were identified as the highest carbon footprint sludge management scenarios. As the quantity of sludge for landfills decreased significantly in 2020, the average GHG emission per ton DS reduced to $0.67 \mathrm{t} \mathrm{CO}_{2}$ /ton DS. In Shanghai, deep dewatering followed by incineration is considered the reasonable and sustainable sludge management scenario. Meanwhile, the challenges need to be overcome as far as the high energy intensity and air pollution control are concerned.

\section{Acknowledgments}

This study was supported by Shanghai Urban Construction Design and Research Institute Co., Ltd. [Grant number CK2020056A].

\section{Conflict of Interest}

No potential conflict of interest was reported by the authors.

\section{References}

1. GU Y., DONG Y., WANG H., KELlER A., XU J., CHIRAMBA T., LI F. Quantification of the water, energy and carbon footprints of wastewater treatment plants in China considering a water-energy nexus perspective. Ecological Indicators, 60, 402, 2016.

2. DONG B., LIU X., DAI L., DAI X. Changes of heavy metal speciation during high-solid anaerobic digestion of sewage sludge. Bioresource Technology, 131, 152, 2013.

3. TUNÇAL T., JANGAM S.V., GÜNEŞ E. Abatement of Organic Pollutant Concentrations in Residual Treatment Sludges: A Review of Selected Treatment Technologies Including Drying. Drying Technology, 29 (14), 1601, 2011.

4. NAHAR N., SHAHADAT HOSSEN M. Influence of sewage sludge application on soil properties, carrot growth and heavy metal uptake. Communications in Soil Science and Plant Analysis, 52 (1), 1, 2021.

5. MURRAY A., HORVATH A., NELSON K.L. Hybrid Life-Cycle Environmental and Cost Inventory of Sewage Sludge Treatment and End-Use Scenarios: A Case Study from China. Environmental Science \& Technology, 42 (9), 3163, 2008.

6. QI M., YANG Y., ZHANG X., ZHANG X., WANG M., ZHANG W., LU X., TONG Y. Pollution reduction and operating cost analysis of municipal wastewater treatment in China and implication for future wastewater management. Journal of Cleaner Production, 253, 120003, 2020.

7. ZHAO G., GARRIDO-BASERBA M., REIFSNYDER S., XU J., ROSSO D. Comparative energy and carbon footprint analysis of biosolids management strategies in water resource recovery facilities. Science of The Total Environment, 665, 762, 2019.

8. ZHAO G., LIU W., XU J., HUANG X., LIN X., HUANG J., LI G. Greenhouse Gas Emission Mitigation of Large-Scale Wastewater Treatment Plants (WWTPs): Optimization of Sludge Treatment and Disposal. Polish Journal of Environmental Studies, 30 (1), 955, 2020;

9. SHI X., ZHENG Y., LEI Y., XUE W., YAN G., LIU X., CAI B., TONG D., WANG J. Air quality benefits of achieving carbon neutrality in China. Science of The Total Environment, 795, 148784, 2021.

10. SUN Y., GARRIDO-BASERBA M., MOLINOSSENANTE M., DONIKIAN N.A., POCH M., ROSSO D. A composite indicator approach to assess the sustainability and resilience of wastewater management alternatives. Science of The Total Environment, 725, 138286, 2020.

11. YANG G., ZHANG G., WANG H. Current state of sludge production, management, treatment and disposal in China. Water Research, 78, 60, 2015.

12. XIAO L., LIN T., WANG Y., YE Z., LIAO J. Comparative life cycle assessment of sludge management: A case study of Xiamen, China. Journal of Cleaner Production, 192, 354, 2018.

13. ZHANG H., SU L., LV T., DONG K. Coupling Heat Pump and Vacuum Drying Technology for Urban Sludge Processing. Energy Procedia, 158, 1804, 2019.

14. MEI X., TANG J., ZHANG Y. Sludge stabilization: Characteristics of the end-products and an alternative evaluative methodology. Waste Management, 105, 355, 2020.

15. EGGEN T., MOEDER M., ARUKWE A. Municipal landfill leachates: a significant source for new and emerging pollutants. Science of the Total Environment, 408 (21), 5147, 2010.

16. YANG K., ZHU Y., SHAN R., SHAO Y., TIAN C. Heavy metals in sludge during anaerobic sanitary landfill: Speciation transformation and phytotoxicity. Journal of Environmental Management, 189, 58, 2017.

17. HAO X., CHEN Q., VAN LOOSDRECHT M.C.M., LI, J., JIANG H. Sustainable disposal of excess sludge: Incineration without anaerobic digestion. Water Research, 170, 115298, 2020.

18. XU T., QIU J., WU Q., GUO X., WEI Z., XIE F., WONG J.W. Fate of heavy metals and major nutrients in a sludgesoil-plant-leachate system during the sludge phytotreatment process. Environmental Technology, 34 (15), 2221, 2013.

19. ZHANG X., WANG X., WANG D. Immobilization of heavy metals in sewage sludge during land application process in China: A review. Sustainability, 9 (11), 2020, 2017.

20. LIU H., XIAO H., FU B., LIU H. Feasibility of sludge deep-dewatering with sawdust conditioning for incineration disposal without energy input. Chemical Engineering Journal, 313, 655, 2017.

21. BRECHTEL H., EIPPER H. Improved efficiency of sewage sludge incineration by preceding sludge drying. Water Science and Technology, 22 (12), 269, 1990. 
22. KOMILIS D., KISSAS K., SYMEONIDIS A. Effect of organic matter and moisture on the calorific value of solid wastes: An update of the Tanner diagram. Waste Management, 34 (2), 249, 2014.

23. ONAT N.C., KUCUKVAR M., TATARI O. Scope-based carbon footprint analysis of US residential and commercial buildings: An input-output hybrid life cycle assessment approach. Building and Environment, 72, 53, 2014.

24. AWASTHI M.K., WANG Q., AWASTHI S.K., WANG M., CHEN H., REN X., ZHAO J., ZHANG Z. Influence of medical stone amendment on gaseous emissions, microbial biomass and abundance of ammonia oxidizing bacteria genes during biosolids composting. Bioresource Technology, 247, 970, 2018.

25. HOUILLON G., JOLLIET O. Life cycle assessment of processes for the treatment of wastewater urban sludge: energy and global warming analysis. Journal of Cleaner Production, 13 (3), 287, 2005.

26. GREENBERG A.E., TRUSSELL R.R., CLESCERI L.S., ASSOCIATION A.W.W. Standard methods for the examination of water and wastewater: supplement to the sixteenth edition. American Journal of Public Health \& the Nations Health, 56, 387, 2005.

27. PELSTER D.E., CHANTIGNY M.H., ROCHETTE P., ANGERS D.A., RIEUX C., VANASSE A. Nitrous oxide emissions respond differently to mineral and organic nitrogen sources in contrasting soil types. Journal of Environmental Quality, 41 (2), 427, 2012.

28. SUZUKI Y., OCHI S., KAWASHIMA Y., HIRAIDE R. Determination of emission factors of nitrous oxide from fluidized bed sewage sludge incinerators by long-term continuous monitoring. Journal of Chemical Engineering of Japan, 36 (4), 458, 2003.

29. PRADEL M., REVERDY A.L. Assessing GHG emissions from sludge treatment and disposal routes: the method behind GESTABoues tool. In ORBIT2012, Global Assessment for Organic Resources and Waste Management, 9, 2012.

30. SINGH R.P., AGRAWAL M. Potential benefits and risks of land application of sewage sludge. Waste Management, 28 (2), 347, 2008.

31. HOSPIDO A., CARBALLA M., MOREIRA M., OMIL F., LEMA J.M., FEIJOO G. Environmental assessment of anaerobically digested sludge reuse in agriculture: potential impacts of emerging micropollutants. Water Research, 44 (10), 3225, 2010.

32. NIU D., HUANG H., DAI X., ZHAO Y. Greenhouse gases emissions accounting for typical sewage sludge digestion with energy utilization and residue land application in China. Waste Management, 33 (1), 123, 2013.

33. LI X., CHEN L., MEI Q., DONG B., DAI X., DING G., ZENG E.Y. Microplastics in sewage sludge from the wastewater treatment plants in China. Water Research, 142, 75, 2018.

34. KELESSIDIS A., STASINAKIS A.S. Comparative study of the methods used for treatment and final disposal of sewage sludge in European countries. Waste Management, 32 (6), 1186, 2012. 